\title{
VARIABEL
}

e-ISSN: 2593-302X dan p-ISSN: 2599-3038

This work is licensed under

a Creative Commons Attribution-NonCommercial 4.0 International License.

\section{Penerapan Model Pembelajaran Problem Solving untuk Meningkatkan Kemampuan Komunikasi Matematis Siswa di SMP}

\author{
Nurul Husna ${ }^{1}$, Munawarah ${ }^{2}$ \\ STKIP Singkawang ${ }^{1}$, STKIP Singkawang ${ }^{2}$ \\ nuna_husna@ymail.com ${ }^{1}$, munawarah.150692@gmail.com²
}

\section{Kata Kunci:}

Problem Solving, Kemampuan

Komunikasi Matematis

\begin{abstract}
ABSTRAK
Penelitian ini bertujuan untuk menerapkan model pembelajaran problem soving untuk dapat melihat perbedaan peningkatan kemampuan komunikasi matematis siswa pada kelas eksperimen dengan kelas kontrol, dan untuk melihat keterlaksanaan model pembelajaran problem solving dalam pembelajaran di kelas VII MTs Ushuluddin Singkawang. Metode yang digunakan dalam penelitian ini adalah metode eksperimen dengan PretestPosttest Control Design. Adapun yang menjadi kelas sampel adalah kelas VII D sebagai kelas ekperimen dan kelas VII E sebagai kelas kontrol yang dipilih dengan teknik probability sampling. Instrumen pengumpulan data menggunakan soal kemampuan komunikasi matematis dan lembar observasi. Berdasarkan hasil analisis data dapat disimpulkan bahwa penerapan model pembelajaran problem solving dapat meningkatkan kemampuan komunikasi matematis siswa pada materi himpunan di kelas VII MTs Ushuluddin Singkawang. Hal tersebut ditunjukkan dengan terdapat perbedaan peningkatan kemampuan komunikasi matematis antara siswa yang diberi pembelajaran model problem solving dengan siswa yang diberi pembelajaran yang konvensional, serta model problem solving terlaksana sangat baik dalam pembelajaran matematika dengan persentase $87,61 \%$ untuk pertemuan pertama dan 92,28\% untuk pertemuan kedua.
\end{abstract}

\section{PENDAHULUAN}

Komunikasi merupakan hal yang harus dimiliki siswa baik dalam kehidupan sehari-hari maupun dalam pembelajaran matematika, karena komunikasi memegang peranan penting dalam proses interaksi pembelajaran di kelas (Kurniawan, 2011). Pentingnya komunikasi juga termuat dalam tujuan pembelajaran matematika di tingkat Sekolah Menengah Pertama (SMP) pada Peraturan Menteri Pendidikan dan Budaya Nomor 64 Tahun 2013. Dalam tujuan tersebut dinyatakan bahwa dalam pembelajaran matematika siswa harus mampu mengkomunikasikan gagasan dengan simbol, tabel, diagram, atau media lain terhadap objek matematika yang dipelajari. Selain itu, Baroody (Wahyuni, 2016) juga menyatakan bahwa paling sedikit ada 2 alasan penting yang menjadikan komunikasi dalam pembelajaran matematika perlu menjadi fokus perhatian yaitu Pertama adalah matematika tidak hanya sekedar alat bantu berfikir, alat untuk menemukan pola, menyelesaikan masalah atau mengambil 
keputusan tetapi matematika juga sebagai alat untuk mengkomunikasikan berbagai ide dengan jelas, tepat dan ringkas. Kedua adalah sebagai aktivitas sosial dalam pembelajaran matematika di sekolah, matematika juga sebagai tempat interaksi antar siswa dan juga sebagai sarana komunikasi guru dan siswa. dengan demikian, keberhasilan siswa dalam belajar matematika dapat diukur melalui komunikasi yang dilakukan siswa dalam pembelajaran matematika, serta mengaplikasikannya dalam kehidupan sehari-hari.

Komunikasi matematis adalah cara untuk menyampaikan ide-ide pemecahan masalah, strategi maupun solusi matematika baik secara tertulis maupun lisan (Pratiwi et al., 2012). Adapun indikator dari komunikasi matematis menurut Walle (2010) yaitu: (1) Mengatur dan menggabungkan pemikiran matematis melalui komunikasi, (2) Mengkomunikasikan pemikiran matematis secara koheren dan jelas kepada teman, guru dan orang lain, (3) Menganalisa, menilai pemikiran dan strategi matematis orang lain, (4) Menggunakan bahasa matematika untuk menyatakan ide matematika, dan (5) Menghubungkan benda nyata, gambar, dan diagram ke dalam ide-ide matematika.

Kemampuan komunikasi matematis mutlak harus dimiliki siswa, baik secara lisan maupun tulisan (Prayitno, 2014), karena komunikasi matematika merupakan suatu peristiwa saling berhubungan atau dialog yang terjadi dalam suatu lingkungan kelas di mana terjadi pengalihan pesan balik secara tertulis maupun lisan yang berisi tentang materi matematika yang dipelajari di kelas. Menurut (Asikin dan Junaedi, 2013) komunikasi yang baik di kelas dapat mengeksploitasi ide matematika dan membantu siswa dalam melihat berbagai keterkaitan materi matematika, dapat mengukur pertumbuhan dan merefleksikan pemahaman siswa, dan sebagai alat untuk mengkonstruksikan pengetahuan matematika, pengembangan pemecahan masalah, peningkatan penalaran, menumbuhkan rasa percaya diri, serta peningkatan keterampilan sosial. Oleh karena itu, agar siswa berhasil dalam belajar matematika, siswa perlu lancar dalam mengkomunikasikan idenya baik secara lisan maupun tulisan.

Namun kenyataannya masih banyak siswa yang kurang terampil dalam menyelesaikan permasalahan dan kurang mampu mengkomunikasikan suatu ide matematika atau sebaliknya mengkomunikasikan peristiwa sehari-hari ke dalam bahasa atau simbol matematika. Kurang mampunya siswa dalam mengkomunikasikan ide-ide matematika dapat dilihat dari hasil penelitian Anisa (2014) dan Qohar (2009), yang menunjukkan bahwa kemampuan komunikasi matematis siswa masih rendah, terutama aspek membaca soal cerita. Ini menunjukkan bahwa kemampuan komunikasi matematis masih jauh dari yang diharapkan. Rendahnya kemampuan komunikasi siswa juga terjadi di Kota Singkawang. Hal tersebut ditunjukkan dari hasil wawancara dengan guru matematika kelas VII di MTs Ushuluddin Singkawang yang menyatakan bahwa rata-rata hasil belajar siswa belum memuaskan sesuai dengan standar yang diharapkan, yaitu kriteria ketuntasan minimal (KKM) dengan nilai 70. Selain itu, saat siswa dihadapakan dengan soal yang membutuhkan analisis, seperti soal cerita, siswa tidak terbiasa menuliskan apa yang diketahui dan apa yang ditanyakan dari soal sebelum menyelesaikannya, sehingga siswa sering salah dalam menafsirkan maksud dari soal tersebut. Sebagian besar siswa merasa kesulitan dalam mengubah suatu permasalahan konstektual ke dalam kalimat matematika, sehingga dapat dikatakan bahwa kemampuan siswa dalam menyampaikan ide atau gagasan matematika secara tertulis dari permasalahan konstektual (soal cerita) masih rendah. Menurut Mariyam (2016), rendahnya kemampuan seseorang dalam menunjukkan kompetensinya disebabkan karena untuk kepentingan penilaian, baik itu untuk tugas maupun ulangan harian, soal-soal yang digunakan adalah soal-soal yang ada di buku ajar, hanya dimodifikasi angka-angkanya saja, sehingga menjadikan matematika sebagai sesuatu yang pasti, kaku, terurut dan prosedural.

Rendahnya kemampuan komunikasi siswa juga didukung dengan hasil prariset yang dilakukan peneliti pada materi himpunan di kelas VII MTs Ushuluddin Singkawang. Peneliti memberikan soal yang memuat kemampuan komunikasi matematis siswa kepada 35 siswa dikelas VII D. Dari hasil prariset diperoleh data bahwa hanya $28,57 \%$ yang dapat menjelaskan ide secara tulisan dengan bentuk gambar, $22,86 \%$ siswa dapat menghubungkan bentuk gambar ke dalam ide-ide matematika; dan hanya 42,87\% siswa yang dapat menyelesaikan soal menyatakan peristiwa sehari-hari ke dalam bahasa atau simbol matematika. Berdasarkan hasil prariset tersebut menunjukkan bahwa kemampuan komunikasi matematis siswa di MTs Ushuluddin Singkawang masih rendah. 
Rendahnya kemampuan komunikasi matematis siswa dapat disebabkan oleh beberapa faktor, satu diantaranya yaitu proses pembelajaran di kelas yang masih menggunakan metode pembelajaran yang konvensional. Dalam proses pembelajaran tersebut perhatian terpusat pada guru, sedangkan siswa menerima pembelajaran secara pasif (Sutikno, 2014). Padahal, posisi siswa selain sebagai penerima pelajaran, siswa juga menjadi subjek yaitu siswa berhak untuk aktif mencari dan memperoleh sendiri pengetahuan dan keterampilan yang dibutuhkan. Oleh karenanya, agar tidak terjadi komunikasi satu arah oleh guru proses pembelajaran matematika di sekolah harus sejalan proses pembejaran yang memungkinkan tercapainya tujuan pembelajaran dalam kurikulum 2013.

Salah satu model pembelajaran yang dimungkinkan dapat diterapkan untuk mengembangkan kemampuan komunikasi matematis siswa adalah model pembelajaran problem solving. Model pembelajaran ini merupakan model yang merangsang berpikir dan menggunakan wawasan tanpa melihat kualitas pendapat yang disampaikan oleh siswa (Yamin, 2012). Selain itu, pemecahan masalah dapat diartikan sebagai suatu proses mental dan intelektual dalam menemukan suatu masalah dan memecahkannya berdasarkan data dan informasi yang akurat sehingga diambil simpulan yang tepat dan cermat (Sutikno, 2014). Penggunaan model pemecahan masalah sangat sesuai diterapkan oleh guru di dalam kelas secara sederhana sehingga membuat siswa komunikatif dalam pembelajaran matematika, dimana siswa mampu menjelaskan ide secara tulisan dari bentuk gambar, siswa mampu mengubah permasalahan matematika ke dalam model matematika dan siswa mampu mengekspresikan ide-ide matematika ke dalam bentuk uraian. Oleh karena itu,tujuan dari penelitian ini adalah untuk menerapkan model pembelajaran problem solving untuk melihat peningkatan kemampuan komunikasi matematis siswa kelas VII di MTs Ushuluddin Singkawang. Dalam penelitian ini juga dilihat apakah terdapat perbedaan peningkatan komunikasi siswa antara kelas yang mendapat pembelajaran problem solving dengan kelas yanng mendapat pembelajaran yang konvensional, serta melihat persentase keterlaksanaan model problem solving dalam pembelajaran matematika.

\section{METODE PENELITIAN}

Metode yang digunakan dalam penelitian ini adalah metode eksperimen dengan Quasi Experimental Design. Adapun rancangan penelitian yang digunakan yaitu Pretest-Posttest Control Group Design. Tahap pertama dilakukan pengukuran dengan pretest, kemudian tahap kedua dikenakan perlakuan (treatment), dan tahap ketiga diakhiri dengan posttest. Populasi dalam penelitian ini adalah seluruh siswa kelas VII MTs Ushuluddin Singkawang. Sampel dalam penelitian ini terdiri dari 2 kelas, yaitu kelas VII D sebagai kelas yang diberi pembelajaran problem solving (kelas eksperimen) dan kelas VII E sebagai kelas yang diberi pembelajaran yang konvensional (kelas kontrol). Adapun teknik pengambilan sampel yang digunakan dalam penelitian ini adalah probability sampling. Menurut Sugiyono (2013) probability sampling adalah teknik pengambilan sampel yang memberikan peluang yang sama bagi setiap unsur (anggota) populasi untuk dipilih menjadi anggota sampel. Cara tersebut dilakukan karena populasi dianggap homogen dengan terlebih dahulu dilakukan uji homogenitas data.

Teknik pengumpulan data yang dipergunakan dalam penelitian ini sebagai berikut: (a) Teknik pengukuran untuk melihat perbedaan peningkatan kemampuan komunikasi siswa antara kelas eksperimen dengan kelas kontrol, dan (b) Teknik observasi langsung untuk melihat keterlaksanaan model pembelajaran pada kelas eksperimen. Instrumen yang digunkan untuk teknik pengukuran berupa soal kemampuan komunikasi matematis dan lembar observasi untuk teknik observasi langsung. Sebelum soal digunakan dalam penelitian, terlebih dahulu diujicobakan yang selanjutnya dianalisis. Berdasarkan hasil ujicoba di MTs Negeri Singkawang diperoleh informasi bahwa soal pre-test, posttest, Rencana Pelaksanaan Pembelajaran (RPP), dan lembar observasi valid untuk digunakan dalam penelitian. Selain itu soal kemampuan komunikasi matematis juga dinyatakan cukup reliabilitas untuk diganakan dalam penelitian dengan tingkat kesukaran sedang.

Teknik analisis data yang digunakan sebagai berikut: (1) untuk menjawab sub masalah pertama: uji NGain digunakan untuk melihat peningkatan kelas eksperimen dan kelas kontrol, lalu menguji perbedaan peningkatan kelas eksperimen dengan kelas kontrol menggunakan T-Test independent. Sebelum uji T-Test Korelasi digunakan maka dianalisis terlebih dahulu uji normalitas dan 
homogenitas. Uji normalitas menggunakan rumus chi-kuadrat sedangkan homogenitas menggunakan uji varians, (2) Untuk menjawab sub masalah kedua tentang keterlaksanaan model pembelajaran problem solving pada materi himpunan akan dilakukan pengolaan data dengan cara mencari persentase keterlaksanaan model pembelajaran problem solving terhadap skor yang dibuat berdasarkan skala Likert.

\section{HASIL DAN PEMBAHASAN}

\section{Kemampuan Komunikasi Matematis Siswa}

Adapun rangkuman hasil pre-test dan post-test kelas ekperimen dan kelas kontrol ditampilkan dalam Tabel 1.

Tabel 1. Nilai Pre-test dan Post-test Kelas Eksperimen dan Kelas Kontrol

\begin{tabular}{lcccc}
\hline \multirow{2}{*}{ Keterangan } & \multicolumn{2}{c}{ Kelas Eksperimen } & \multicolumn{2}{c}{ Kelas Kontrol } \\
\cline { 2 - 5 } & Pretest & Posttest & Pretest & Posttest \\
\hline Rata-rata & 42,57 & 64,86 & 34,55 & 54,85 \\
Standar Deviasi & 22,14 & 19,76 & 20,17 & 16,98 \\
\hline
\end{tabular}

Berdasarkan data dalam Tabel 1 tersebut dapat dikatakan bahwa terjadi peningkatan kemampuan komunikasi matematis siswa pada kelas eksperimen dan kelas kontrol. Untuk melihat besarnya peningkatannya, maka dilakukan uji N-Gain yang hasilnya disajikan dalam Tabel 2.

Tabel 2. Nilai N-Gain Kelas Eksperine dan Kontrol

\begin{tabular}{ccc}
\hline Kelas & Nilai N-Gain & Kriteria \\
\hline Eksperimen & 0,46 & Sedang \\
Kontrol & 0,31 & Sedang \\
\hline
\end{tabular}

Untuk melihat apakah terdapat berbedaan peningkatan kemampuan komunikasi matematis antara siswa di kelas eksperimen dan kelas kontrol dilakukan pengujian hipotesis dengan t-test independent dengan terlebih dahulu data dinyatakan normal dan homogen berdasarkan hasil analisis data diketahui bahwa nilai $\boldsymbol{t}_{\text {hitung }}$ yaitu 2,46 dan nilai $\mathrm{t}_{\text {tabel }}$ dengan taraf signifikan $(\alpha) 5 \%$ yaitu 2,042. Dari data tersebut maka $\boldsymbol{t}_{\text {hitung }}>\mathbf{t}_{\text {tabel }}$ atau 2,46 $>2,0$ yang berarti bahwa $\mathrm{H}_{0}$ ditolak dan $\mathrm{H}_{\mathrm{a}}$ di terima. Maka dapat disimpulkan bahwa terdapat perbedaan peningkatan kemampuan komunikasi matematis siswa antara kelas eksperimen dengan kelas kontrol.

\section{Keterlaksanaan Model Pembelajaran Problem Solving}

Berdasarkan lima tahap pembelajaran yang dimiliki problem solving dikembangkan menjadi 21 indikator yang akan di observasi. Adapun ringkasan data hasil observasi pertemuan pertama dan kedua dapat dilihat pada Tabel 3.

Tabel 3. Keterlaksanaan Proses Pembelajaran

\begin{tabular}{ccc}
\hline \multirow{2}{*}{$\begin{array}{c}\text { Pembelajaran Model } \\
\text { Problem Solving }\end{array}$} & \multicolumn{2}{c}{ Pertemuan ke- } \\
\cline { 2 - 3 } & \multicolumn{2}{c}{2} \\
\hline Kriteria & Sangat Baik & Sangat Baik \\
\hline
\end{tabular}

Dari Tabel 3 dapat diketahui bahwa terdapat peningkatan keterlaksanaan model pembelajaran problem solving dari pertemuan pertama ke pertemuan kedua dengan selisih 4,67\%. 
Dari hasil penelitian menunjukkan bahwa pembelajaran matematika menggunakan model pembelajaran problem solving pada materi himpunan yang diterapkan dikelas VII D dapat meningkatkan kemampuan komunikasi matematis siswa secara signifikan. Ini dapat dilihat dari hasil tes kemampuan komunikasi matematis siswa setelah diberikan pembelajaran dengan menggunakan model pembelajaran problem solving yang lebih tinggi dari pada hasil tes kemampuan komunikasi matematis siswa dengan metode pembelajaran konvensional. Terjadinya penigkatan kemampuan komunikasi siswa di dukung dengan keterlaksanaan model pembelajaran problem solving, secara umum peneliti sudah melaksanakan serangkaian kegiatan pembelajaran tersebut dengan baik. Hal ini terbukti dari lima tahap pembelajaran yang dimiliki oleh model pembelajaran problem solving kemudian dikembangkan menjadi 21 indikator. Berdasarkan lima tahap pembelajaran yang dimiliki model pembelajaran problem solving pada pertemuan pertama yaitu menyajikan masalah, mengidentifikasi masalah, mencari alternatif pemecahan masalah dan menilai setiap alternatif pemecahan masalah menunjukkan keterlaksanaan yang sangat baik dan tahap menarik kesimpulan memiliki keterlaksanaan yang baik. Untuk pertemuan kedua kelima tahap pembelajaran tersebut menunjukkan keterlaksanaan yang sangat baik.

\section{SIMPULAN DAN SARAN}

\section{Kesimpulan}

Berdasarkan hasil analisis data dapat disimpulkan bahwa penerapan mdel pembelajaran problem solving dapat meningkatkan kemampuan komunikasi matematis siswa pada materi himpunan di kelas VII MTs Ushuluddin Singkawang. Hal tersebut ditunjukkan dengan terdapat perbedaan peningkatan kemampuan komunikasi matematis antara siswa yang diberi pembelajaran model problem solving dengan siswa yang diberi pembelajaran yang konvensional, serta model problem solving terlaksana sangat baik dalam pembelajaran matematika dengan persentase $87,61 \%$ untuk pertemuan pertama sebesar $87,61 \%$ dan $92,28 \%$ untuk pertemuan kedua.

\section{Saran}

Berdasarkan pembahasan dan hasil penelitian serta kesimpulan yang telah didapat, terdapat beberapa saran dari peneliti untuk penyempurnaan penelitian sejenis selanjutnya. Beberapa saran tersebut yaitu diupayakan agar siswa lebih memperhatikan penjelasan guru selama proses belajar mengajar yang berlangsung, dan model pembelajaran problem solving yang diterapkan pada materi himpunan dapat diterapkan juga pada materi matematika yang lainnya.

\section{DAFTAR PUSTAKA}

Anisa, W.N. (2014). Peningkatan Kemampuan Pemecahan Masalah dan Komunikasi Matematik Melalui Pembelajaran Pendidikan Matematika Realistik untuk Siswa SMP Negeri di Kabupaten Garut. Jurnal Pendidikan dan Keguruan, 1(1).

Asikin, M., \& Junaedi, I. (2013). Kemampuan Komunikasi Matematika Siswa SMP dalam Setting Pembelajaran RME (Realistic Mathematics Education). Unnes Journal of Mathematics Education Research, 2(1).

Kurniawan, D. (2011). Pembelajaran Terpadu (Teori, Praktik, dan Penilaian). Bandung: Pustaka Cendekia Utama.

Mariyam, Sugiatno, \& Suratmat, D. (2016). Pengembangan Soal untuk Mengukur Kemampuan Komunikasi dan Translasi Representasi Matematis Siswa Sekolah Menengah Pertama. Jurnal Pendidikan dan Pembelajaran, 5(5).

Pratiwi, D.D. (2013). Kemampuan Komunikasi Matematis dalam Pemecahan Masalah Matematika sesuai dengan Gaya Kognitif pada Siswa Kelas IX SMP Negeri 1 Surakarta Tahun Pelajaran 2012/2013. Disertasi. Surakarta: Universitas Sebelas Maret. 
Prayitno, A.T. (2014). Pembelajaran Matematika dengan Model Pembelajaran Kooperatif Tipe FSLC Bernuansa Konstruktivisme pada Materi Turunan Fungsi untuk Meningkatkan Kemampuan Komunikasi Matematis Siswa SMA. Euclid, 1(1).

Sugiyono. (2013). Metode Penelitian Pendidikan. Bandung: Alfabeta.

Sutikno, M.S. (2014). Metode dan Model-Model Pembelajaran. Lombok: Holistica.

Wahyuni, R., Utami, C., \& Husna, N. (2016). Pengaruh Model Role Playing terhadap Kemampuan Komunikasi Matematis Siswa pada Materi Fungsi Komposisi Kelas XI SMA Negeri 6 Singkawang. Jurnal Pendidikan Matematika Indonesia, 1(2), 81-86.

Walle, J.V.D. (2010). Matematika Sekolah Dasar dan Menengah Pengembangan Pengajaran. Jakarta: Erlangga. 